\title{
Prepoznavanje mam s poporodno depresijo in pomen ocenjevanja vedenja novorojenčka za spodbujanje njihovega odnosa s starši na enoti intenzivne nege novorojenčkov
}

\author{
Nastja Pucer ${ }^{1 * \#}$, Jana Kodrič²\#, Albina Gubanc ${ }^{2}$ in Darja Paro Panjan ${ }^{2}$ \\ ${ }^{1}$ Zdravstveni dom Trbovlje \\ ${ }^{2}$ Univerzitetni klinični center Ljubljana, Pediatrična klinika
}

\begin{abstract}
Povzetek: Rojstvo bolnega ali nezrelega otroka ter zgodnja ločitev otroka od mame zaradi hospitalizacije $v$ obdobju novorojenčka sta pomembna dejavnika tveganja za razvoj poporodne depresije pri mamah. V prispevku je predstavljeno ugotavljanje pogostosti simptomov poporodne depresije pri mamah novorojenčkov, zdravljenih na Kliničnem oddelku za neonatologijo Pediatrične klinike v Ljubljani, ter preverjanje uporabnosti Brazeltonove lestvice za ocenjevanje vedenja novorojenčka kot pripomočka za spodbujanje interakcije med starši in otroki ter kot pripomočka za povečevanje starševskih kompetenc. V raziskavi je pri oceni poporodnega depresivnega razpoloženja sodelovalo 63 mam, katerih novorojenček je bil hospitaliziran na Kliničnem oddelku za neonatologijo Pediatrične klinike v Ljubljani, pri oceni vedenja novorojenčkov pa 26 novorojenčkov in njihovih staršev (12 mam je sodelovalo pri obeh delih raziskave). Rezultati kažejo, da zgodnja hospitalizacija novorojenčka predstavlja dejavnik, ki lahko vpliva na izraženost poporodnega depresivnega razpoloženja pri mamah, saj je bil odstotek mam, ki dosegajo razmejitveno točko za presejanje poporodne depresije na Edinburški lestvici poporodne depresije (EPDS), višji v primerjavi s pojavnostjo poporodne depresije v slovenskem prostoru. Rezultati potrjujejo potrebo po uporabi pripomočka za odkrivanje poporodne depresije pri mamah bolnih novorojenčkov in kažejo na možno korist uporabe NBAS za spodbujanje odnosa med starši in novorojenčkom.
\end{abstract}

Ključne besede: poporodna depresija, odnos med starši in novorojenčkom, Brazeltonova lestvica ocenjevanja vedenja novorojenčka (NBAS), hospitalizacija dojenčkov

\section{Identifying mothers with postpartum depressions and the use of Neonatal Behavior Assessment Scale to support parent- infant interaction at the neonatal intensive care unit}

\author{
Nastja Pucer' ${ }^{1}$ Jana Kodrič², Albina Gubanc ${ }^{2}$ and Darja Paro Panjan² \\ ${ }^{\prime}$ Community Health Centre Trbovlje, Slovenia \\ ${ }^{2}$ University Medical Centre Ljubljana, Division of Paediatrics, Slovenia
}

\begin{abstract}
Birth of an ill or premature infant and early separation from the mother on behalf of admission to a neonatal intensive care unit was found to be one of the most important predictors of postpartum depression. The goals of the study were to examine the postpartum depression symptoms frequency in the group of mothers of infants in the neonatal intensive care unit (NICU) at Pediatric Clinic of Ljubljana, and to examine the clinical use of the Neonatal Behavioral Assessment Scale (NBAS) to support the mother-infant bonding and to promote parental competencies. 63 mothers of infants in NICU participated in the study about postpartum depression symptoms frequency and 26 infants and their parents participated in the assessment of the neonatal behavior (12 mothers participated in both parts of the study). The results showed that early hospitalization of the newborn increases the risk of postnatal depression in mothers. The percent of mothers who scored 10 or more points on the Edinburgh Postnatal Depression Scale (EPDS) was higher than the incidence of postpartum depression in Slovenia. Results support the need of a postpartum depression screening tool for mothers of infants at NICU and show that the use of NBAS is a potentially useful tool to promote parent-infant interaction.
\end{abstract}

Keywords: postnatal depression, mother-infant interaction, Neonatal Behavioral Assessment Scale (NBAS), infant hospitalization

\footnotetext{
"Naslov/Address: Nastja Pucer, univ. dipl. psih., Zdravstveni dom Trbovlje, Rudarska cesta 12, 1420 Trbovlje, e-pošta: nastjapucer@ gmail.com
}

\#Nastja Pucer in Jana Kodrič sta v enaki meri prispevali k nastanku prispevka.

Članek je licenciran pod pogoji Creative Commons Attribution 4.0 International licence. (CC-BY licenca).

The article is licensed under a Creative Commons Attribution 4.0 International License (CC-BY license). 
Rojstvo otroka je za družino prijeten, a tudi težaven in stresen dogodek, saj s seboj prinaša veliko sprememb in zahteva številne prilagoditve. Izvore stiske ob prehodu v starševstvo lahko predstavljajo spremembe, povezane s prevzemanjem odgovornosti, splošnim upadom partnerskega zadovoljstva, znižanjem samopodobe pri ženskah, otrokovimi temperamentnimi značilnostmi, previsokimi pričakovanji glede samoučinkovitosti ali občutki pomanjkanja podpore (Carr, 2006). Prilagajanje je posebej zahtevno, kadar je bila nosečnost nepričakovana ali se stvari niso izšle tako, kot sta partnerja pričakovala, če sta imela težave $\mathrm{z}$ zanositvijo ali se jima je rodil bolan oziroma mrtev otrok (Pope idr., 2000a).

\section{Depresivna simptomatika v poporodnem obdobju}

Poleg prilagoditvenih težav ob rojstvu novorojenčka se pri osmih od desetih žensk po porodu pojavi poporodna otožnost, ki predstavlja normalno stanje in se kaže kot nenadne spremembe razpoloženja, tesnoba, razdražljivost, težave s spanjem, zmanjšan tek ter pretirana dejavnost oziroma pomanjkanje energije. Med duševnimi motnjami, ki se pojavljajo po porodu, razlikujemo med poporodno psihozo, ki se nenadoma in očitno pojavi pri $0,1 \%$ žensk, ter poporodno depresijo, ki je težje prepoznavna in pogostejša. Pojavi se od štiri do šest tednov po porodu, lahko tudi pozneje, ter traja od treh do šestih mesecev, lahko pa tudi veliko dlje (Drglin, 2009). Ocene pogostosti poporodne depresije se gibljejo od 3 do $33 \%$, najpogosteje med 10 in $20 \%$ (Koprivnik in Plemenitaš, 2009), razlike pa so verjetno posledica različnih diagnostičnih kriterijev ter dejstva, da so študije zajele ženske v različnih obdobjih po porodu (Skočir, 2005).

Tako Mednarodna klasifikacija bolezni-International Classification of Diseases ICD 10 (World Health Organization - WHO, 1992) kot tudi Diagnostični in statistični priročnik duševnih motenj - Diagnostic and Statistical Manual of mental disorders DSM IV (American Psychiatric Association - APA, 1994) poporodnih duševnih motenj ne obravnavata kot samostojne kategorije. Klinično se namreč poporodna depresija ne razlikuje od depresije $\mathrm{v}$ drugih življenjskih obdobjih oziroma okoliščinah, zato uporabljajo za odkrivanje obeh enake diagnostične kriterije (pregled v APA, 1994). Kljub temu pa nekateri avtorji opozarjajo na dodatne oziroma specifične simptome poporodne depresije, kot so ambivalentna ali negativna čustva do otroka, posvečanje prevelike pozornosti otrokovemu zdravju, ki lahko meji na obsesivnost, ter občutke nesposobnosti (Koprivnik in Plemenitaš, 2009). Občutka krivde in nesposobnosti sta med najbolj pogostimi simptomi poporodne depresije, ko se ženskina pričakovanja ne skladajo z realno izkušnjo materinstva oziroma, ker mislijo, da niso dobre mame, če se pri njih pojavljajo take misli (Holden, Sagovsky in Cox, 1989). Dejavniki tveganja za nastanek poporodne depresije so prenatalna depresija, stres kot posledica nege in skrbi za otroka, stresni življenjski dogodki med nosečnostjo in po porodu, nezadostna socialna podpora, prenatalna anksioznost, nezadovoljstvo s partnersko zvezo, pretekla depresivna epizoda prednosečnostjo, težaven temperament otroka, pretekla izkušnja poporodne otožnosti, nizko samospoštovanje, nizek socialnoekonomski status, samski stan ter nenačrtovana in/ali nezaželena nosečnost (Beck, 2002). Opozorilni znaki stisk zaradi različnih razlogov, kot so npr. sram, krivda ali strah pred obsojanjem, niso vedno očitni ali vidni, saj ženske svoje občutke pogosto prikrivajo in navzven predstavljajo bolj socialno sprejemljive tegobe (utrujenost, glavobol, zahtevnost dojenčka ...) zaradi česar poporodna depresija pogosto ni prepoznana (Drglin, 2009).

Zgodnja prepoznava in obravnava poporodne depresije je ključna, saj z zdravljenjem močno vplivamo na potek depresije (Lee, Yip, Leung in Chung, 2000). Prepoznavanje simptomov ter razlikovanje poporodne depresije od drugih razpoloženjskih in anksioznih motenj je nujno potrebno za ustrezno obravnavo, ki je lahko psihoterapevtska, medikamentozna ali kombinacija obeh (Globevnik Velikonja, 2009a). Poporodna depresija je razmeroma lahko ozdravljiva, če ženska pravočasno poišče pomoč (Globevnik Velikonja, 2009a) in običajno izzveni po enem letu zdravljenja (Koprivnik in Plemenitaš, 2005).

\section{Učinek mamine poporodne depresije na otroka in družino}

Poporodna depresija ne prizadene le kakovosti življenja ženske, temveč tudi kakovost življenja njenega novorojenčka in drugih otrok, partnerja ter ostalih bližnjih (Cox in Holden, 2003; Koprivnik in Plemenitaš, 2009). Izsledki raziskav, ki ugotavljajo učinek mamine poporodne depresije na otrokov razvoj, so različni. Nekateri avtorji (npr. Cox in Holden, 2003; Holden idr., 1989; Murray in Cooper, 1996; Murray idr., 2010) navajajo, da mamina poporodna depresija pomembno učinkuje na manj optimalen kognitivni, vedenjski in čustveni razvoj otroka, negativen učinek pa ima tudi na komunikacijo in interakcijo z otrokom.

\section{Zgodnja hospitalizacija novorojenčka}

Prezgodnje rojstvo in/ali rojstvo bolnega otroka je za starše običajno nepričakovan, stresen in travmatičen dogodek, na katerega se pogosto težko prilagodijo in ga težko sprejmejo (Erdem, 2010). Prevzemata jih občutka odgovornosti in krivde. Mame imajo pogosto občutek, da bi morale ravnati drugače, da ne bi prišlo do tega, ter da so one tiste, ki so spravile dojenčka v nevarnost (Brazelton, 1999). Ločitev mame in otroka zaradi hospitalizacije otroka v prvih dneh po porodu poveča negotovost mame, saj se običajno počuti nepomembna za otroka (še posebej v primeru, ko otroka ne doji in ne neguje), kar poveča dvom v njeno materinsko vlogo (Flacking, Ewald, Hedberg Nyqvist in Starrin, 2006).

Starši otrok, ki se zdravijo na enoti intenzivne nege novorojenčkov - EINN (angl. Neonatal Intensive Care Unit - NICU), občutijo izgubo, saj žalujejo za zdravim 
otrokom, ki so ga pričakovali, ali žalujejo za zadnjimi meseci nosečnosti, ki so jim bili odvzeti v primeru prezgodnjega poroda. Prestrašeni so, skrbi jih preživetje njihovega novorojenčka, obenem pa se počutijo nemočne (Hawthorne, 2005). Rojstvo bolnega, prizadetega ali zelo nezrelega otroka z zgodnjo ločitvijo otroka od mame je tudi pomemben dejavnik tveganja za razvoj poporodne depresije pri mamah (Globevnik Velikonja, 2009b). Z. Yurdakul idr. (2009) navajajo, da sta stopnji anksioznosti in depresivnosti pri mamah višji, kadar je njihov otrok zdravljen na EINN, kot pri mamah zdravih novorojenčkov. Y. Erdem (2010) ugotavlja, da sta anksioznost in depresivnost staršev višji ob daljši hospitalizaciji otroka in kadar je bila nosečnost visoko tvegana.

Starši, ki so imeli otroka na EINN, poročajo, da je bila najbolj stresna izkušnja ta, da so videli otrokovo trpljenje, a mu niso mogli/znali pomagati (Gale, Franck, Kools in Lynch, 2004). Pogosto se počutijo prestrašeni, nemočni, krivi, jezni, razočarani ter popolnoma brez nadzora nad dogajanjem. Z vključitvijo $\mathrm{v}$ nego svojega otroka med hospitalizacijo se njihova negotovost običajno zmanjša, kompetentnost v starševski vlogi pa zviša (Gale idr., 2004; Globevnik Velikonja, 2009b). Starše običajno najbolj skrbi, ali bo otrok preživel ter kakšne bodo dolgoročne posledice bolezni na otrokov razvoj (Johnson, 2011). Otrokova bolezen in skrb glede posledic le-te za otrokov nadaljnji razvoj, pomanjkanje informacij ter pomanjkanje socialne podpore delujejo negativno na oblikovanje vezi med mamo in otrokom. Omenjeni dejavniki lahko znižajo tudi mamino samospoštovanje, povečajo depresivno simptomatiko ter povečajo stresno doživljanje situacije (pregled raziskav v Flacking idr., 2006).

\section{Uporaba Brazeltonove lestvice za ocenjevanje vedenja novorojenčka (NBAS) kot pripomočka za spodbujanje zgodnjega odnosa med starši in otrokom}

Brazeltonovo lestvico ocenjevanja vedenja novorojenčka (Neonatal Behavioral Assessment Scale NBAS) je razvil dr. T. Berry Brazelton in jo leta 1973 tudi prvič objavil. Temelji na spoznanjih o novorojenčku kot kompetentnem in kompleksno organiziranem bitju, ki je sposobno interakcije z okoljem in se na dražljaje selektivno odziva (Brazelton in Nugent, 2001). S pomočjo NBAS spoznavamo vedenjski razpon odzivanja novorojenčka na dražljaje iz okolja, ocenjujemo njegova stanja čuječnosti ter njegove sposobnosti za prilagajanje in obvladovanje novega okolja. Ocenjevanje novorojenčkovega vedenja izvajamo $v$ navzočnosti staršev, ob tem se $z$ njimi pogovarjamo o otrokovem vedenju in odzivanju, jih opozarjamo na posebnosti otrokovega odzivanja (na morebitne šibkosti in kompetence) ter s tem povečujemo njihovo občutljivost in sposobnost prepoznavanja otrokovih vedenjskih značilnosti (Brazelton, 1999).

Številne raziskave so analizirale različne aspekte uporabnosti NBAS. Pri proučevanju povezave med mamino depresijo in otrokovim vedenjem so raziskovalci (npr. Diego, Field in Hernandez-Reif, 2005; Jones idr., 1998; Lundy idr., 1999; Murray, Stanley, Hooper, King in Fiori-Cowley, 1996) ugotovili, da otroci mam, ki trpijo za poporodno depresijo, dosegajo manj optimalne rezultate na NBAS v primerjavi z otroki mam, ki nimajo znakov poporodne depresije. Pri mamah, ki so rodile nedonošenčka, so trpele za poporodno depresijo ali imele težave pri interakciji s svojim otrokom, se NBAS uporabili kot pripomoček za spodbujanje interakcije med mamo in novorojenčkom.

Pri uporabi NBAS starši v sodelovanju z zdravstvenim osebjem skupaj odkrivajo novorojenčkove značilnosti in njegov način sporočanja svojih potreb ter se učijo ustreznega odzivanja nanje (Hawthorne in Hutchon, 2008). Starši tako pridobijo zaupanje vase in v svoje sposobnosti, da bodo znali razumeti in skrbeti za svojega otroka. Lažje tudi prepoznavajo otrokove potrebe in posledično učinkoviteje ukrepajo. Uporaba NBAS poveča mamino samozaupanje in odzivnost $\mathrm{v}$ interakciji z otrokom; očetje, ki sodelujejo pri izvedbi, se pri otroku staremu en mesec bolj vključujejo v skrb zanj kot tisti, ki ne sodelujejo pri izvedbi, pri mamah otrok, ki so bili zdravljeni na EINN, pa ima uporaba NBAS pozitiven učinek na njihovo zaznavo otroka (Hawthorne, 2009). NBAS je obenem koristen tudi za zdravstveno osebje, ki poleg tega, da spoznava novorojenčka, spoznava tudi starše in njihov način komunikacije ter tako lažje razume njihovo odzivanje na otroka (Hawthorne in Hutchon, 2008).

Ker zgodnja hospitalizacija novorojenčka predstavlja pomemben dejavnik, ki lahko vpliva na izraženost poporodnega depresivnega razpoloženja pri mamah, smo želeli z raziskavo ugotoviti pogostost simptomov poporodne depresije pri mamah novorojenčkov, ki so bili hospitalizirani na Kliničnem oddelku za neonatologijo Pediatrične klinike $\mathrm{v}$ Ljubljani. V raziskavi smo želeli preveriti tudi možnosti in koristnosti uvajanja uporabe NBAS kot pripomočka za spodbujanje interakcije med starši in bolnimi novorojenčki. Zanimalo nas je, kako bo izvedba NBAS vplivala na mamino oceno otrokovih značilnosti in kako bodo ocenile koristnost njegove izvedbe. Ker se NBAS uporablja tudi kot pripomoček za povečevanje starševskih kompetenc, nas je zanimalo, ali se izraženost poporodnega depresivnega razpoloženja pri mamah bolnih novorojenčkov razlikuje glede na to, ali so mame sodelovale pri NBAS ali ne.

\section{Metoda}

\section{Udeleženci}

$\mathrm{V}$ prvem delu raziskave (oceni depresivnega razpoloženja) je sodelovalo 63 mam, katerih novorojenčki so bili hospitalizirani na Kliničnem oddelku za neonatologijo Pediatrične klinike v Ljubljani.

$\mathrm{V}$ drugem delu raziskave, oceni vedenja novorojenčka, je sodelovalo 26 novorojenčkov (16 dečkov in 10 deklic) in njihovih mam, pri katerih smo izvedli NBAS. Povprečna 
starost mam je bila 29,9 let $(S D=5,1), 14$ je bilo prvorodk, za deset žensk je bil to drugi otrok, za dve pa tretji otrok. 24 mam je v času hospitalizacije bivalo v bolnišnici, dve pa doma. Vabilu k sodelovanju pri drugem delu raziskave so se odzvale vse mame, dvanajst izmed njih pa je sodelovalo tudi pri prvem delu raziskave.

\section{Pripomočki}

\section{Edinburška lestvica poporodne depresije}

Izraženost intenzitete poporodnega depresivnega razpoloženja smo merili z Edinburško lestvico poporodne depresije (Edinburgh Postnatal Depression Scale EPDS; Cox, Holden in Sagovsky, 1987, v Koprivnik in Plemenitaš, 2005), ki sta ga P. Koprivnik in A. Plemenitaš (2005) priredili za slovensko uporabo.

EPDS je presejalni vprašalnik za prepoznavanje poporodne depresije, sestavljen iz desetih enostavnih vprašanj o počutju mame $\mathrm{v}$ zadnjem tednu (1. Uspe mi, da se nasmejim in vidim smešno plat stvari, 2. Veselim se stvari, 3. Po nepotrebnem se obremenjujem, kadar gredo stvari narobe, 4. Brez pravega razloga sem tesnobna in zaskrbljena, 5. Brez pravega razloga se počutim prestrašeno ali panično, 6. Stvari se mi nakopičijo, 7. Bila sem tako nesrečna, da sem slabo spala, 8. Počutila sem se žalostno ali nesrečno, 9. Bila sem tako nesrečna, da sem jokala, 10. Pomislila sem, da bi si kaj naredila). Z njim določamo le intenziteto depresivnega razpoloženja in ne diagnoze (za slednje je namreč potreben kliničen pregled). Vprašalnik je zelo enostaven za uporabo, mame pri vsakem vprašanju označijo odgovor, ki kar najbolje opisuje njihovo počutje v zadnjih sedmih dneh. Odgovori se nato vrednotijo z 0,1 , 2 ali 3 točkami (pri tem 0 pomeni najboljše in 3 najslabše počutje; najnižji možni seštevek je 0 , najvišji pa 30 točk; Koprivnik in Pleminitaš, 2009).

Cox in Holden (2003) navajata, da je pri uporabi razmejitvene točke 10 občutljivost 86-odstotna in specifičnost 78-odstotna, koeficient zanesljivosti $\alpha$ vprašalnika EPDS pa je 0,87. Tudi avtorici slovenske priredbe EPDS (Koprivnik in Plemenitaš, 2005) menita, da je razmejitvena točka pri vrednosti 10 primerna za presejanje poporodnih depresij pri nas, medtem ko je razmejitvena točka za odkrivanje težjih oblik poporodne depresije 13 .

Zaradi različnih opredelitev poporodnega obdobja (pregled v Koprivnik in Plemenitaš, 2009; Skočir, 2005) ni jasnih smernic o časovni ustreznosti izvajanja presejalnega preizkusa EPDS, čeprav Cox in Holden (2003) svetujeta izpolnjevanje EPDS šest tednov po porodu.

\section{Brazeltonova lestvica za ocenjevanje vedenja novorojenčka}

Brazeltonova lestvica ocenjevanja vedenja novorojenčka (Neonatal Behavioral Assessment Scale - NBAS; Brazelton in Nugent, 2001) je med kliniki in raziskovalci najbolj razširjen in vsestranski pripomoček za ocenjevanje vedenja novorojenčka (Alberts, 2005). Od nastanka dalje predstavlja za strokovnjake s področja skrbi za zdravje novorojenčkov pomemben pripomoček, s katerim pomagajo staršem bolje razumeti novorojenčkove sposobnosti, vedenjske vzorce in temperament. Izvedba preizkusa $\mathrm{v}$ prisotnosti staršev in sodelovanju $\mathrm{z}$ njimi omogoča strokovnjaku in staršem ob skupnem opazovanju ter raziskovanju novorojenčkovega vedenja izhodišče za pogovor (Nugent, 1985). NBAS predstavlja celovit profil delovanja novorojenčka, ki vključuje njegove kompetence in močna področja ter obenem odkriva težave in odklone od pričakovanega vedenja. Ponavljanje ocenjevanj omogoča spremljanje in ocenjevanje napredka novorojenčkovega vedenja po različnih dimenzijah.

NBAS temelji na treh ključnih predpostavkah (Brazelton in Nugent, 2001):

- Novorojenčki ob rojstvu uporabljajo vseh pet čutov (vid, sluh, okus, tip, voh), s katerimi spoznavajo okolje in svoje vedenjske odzive na okolje lahko nadzorujejo.

- Vedenje novorojenčkov je kompleksno organizirano. Njihovo vedenje ni le odzivanje na zunanje dražljaje (npr. odzivanje na ogovarjanje staršev), temveč lahko S svojim vedenjem vplivajo na odziv okolice (npr. $\mathrm{z}$ jokom).

- Novorojenček je socialno bitje, posameznik z lastno osebnostjo, pripravljen, da s svojim vedenjem spreminja okolico in prilagaja svoje vedenje kot odziv na zahteve okolice.

Vedenje novorojenčka ocenjujemo na štirih ravneh funkcioniranja, ki so med seboj hierarhično organizirane. Obvladanje razvojnih nalog na posamezni ravni omogoča napredovanje na višjo raven. Ravni razvojnega funkcioniranja so naslednje (Brazelton in Nugent, 2001):

1. Uravnavanje avtonomnih funkcij (uravnavanje dihanja in telesne temperature) predstavlja temeljno raven funkcioniranja in je predpogoj za višje ravni.

2. Organizacija gibanja predstavlja zmožnost uravnavanja mišičnega tonusa, novorojenčkovih gibov in raven aktivnosti, prisotnost integriranih gibalnih dejanj (npr. gibi roke proti ustom, zaščitni gibi). Odraz organizacije gibanja in zrelosti osrednjega živčevja predstavljajo tudi refleksi.

3. Uravnavanje stanj čuječnosti predstavlja zmožnost prehajanja med stanji čuječnosti, raven razdražljivosti, vzburjenja, zmožnost samopomiritve in zmožnost neodzivanja na nepomembne dražljaje oz. habituacije. Predpogoj za opazovanje in ocenjevanje načinov uravnavanja stanj predstavlja razlikovanje med šestimi stanji, od katerih sta dve stanji spanja (globoko spanje in rahlo spanje) ter štiri stanja budnosti (dremanje, aktivna budnost, vznemirjenost in jok).

4. Vključevanje novorojenčka v socialno interakcijo je možno, kadar so vse podrejene ravni novorojenčkovega funkcioniranja v ravnovesju. Novorojenček raziskuje 
okolico z vidom, sluhom in drugimi čuti ter se vključuje in odziva $\mathrm{v}$ komunikaciji $\mathrm{z}$ drugimi osebami.

Najpomembnejša naloga novorojenčka je integracija vseh štirih ravni funkcioniranja. Čeprav poteka razvoj po posameznih ravneh funkcioniranja zaporedno, le-ta ni povsem linearen in lahko kot odziv na stresorje opazimo znake stresa tudi na vsaki od hierarhično nižjih ravneh funkcioniranja.

NBAS sestavlja 53 postavk (28 vedenjskih, 18 refleksov in 7 dodatnih postavk), od katerih 32 vedenj izzovemo pri rokovanju $\mathrm{z}$ novorojenčkom, ostale pa ocenimo na osnovi opazovanja novorojenčkovih odzivov med celotnim pregledom ali ob izzvanih vedenjih. Razen refleksov, ki jih ocenjujemo na štiristopenjski lestvici, ostala vedenja ocenjujemo na devetstopenjski lestvici (Brazelton in Nugent, 2001). Pri vrednotenju upoštevamo opise posameznih stopenj vsake lestvice (podrobnejši opis v Brazelton in Nugent, 2001).

Vprašalnik za ocenjevanje otrokovih značilnosti in doživljanja mam

Za pridobivanje dodatnih informacij o nekaterih otrokovih temperamentnih značilnostih in doživljanju mam ter za ovrednotenje koristnosti uporabe NBAS smo uporabili dva vprašalnika, ki smo ju oblikovali sami.

Vprašalnik, ki so ga mame reševale pred izvedbo $N B A S$, je bil razdeljen na tri vsebinske dele. V prvem delu smo zbirali nekatere podatke o mami, npr. njihovo starost, število otrok. V drugem delu so bile navedene različne trditve o vedenju in čustvih otrok in mam (npr. Skrb za otroka se mi zdi zelo stresna oziroma nestresna; Moj otrok je zelo razdražljiv oziroma zelo miren.). Tu so mame s pomočjo petstopenjske lestvice ocenile njihovo ali otrokovo trenutno stanje. V tretjem delu je sledilo še odprto vprašanje, kjer smo jih spraševali, glede česa so trenutno najbolj zaskrbljene.

Vprašalnik, ki so ga mame izpolnjevale po opravljenem $N B A S$, je vseboval enak drugi in tretji vsebinski del vprašalnika, ki so ga mame izpolnjevale pred izvedbo NBAS. Poleg tega pa je vključeval še nekatere trditve o NBAS (npr. NBAS se mi je zdel zelo koristen oziroma nekoristen.), kjer smo jih prosili, da pri vsaki trditvi obkrožijo številko odgovora, s katerim se najbolj strinjajo. Vsebina obeh vprašalnikov je razvidna $\mathrm{v}$ poglavju Rezultati.

\section{Postopek}

V prvem delu raziskave, ugotavljanju izraženosti poporodnega depresivnega razpoloženja pri mamah novorojenčkov, ki so bili hospitalizirani na Kliničnem oddelku za neonatologijo Pediatrične klinike v Ljubljani, smo v obdobju devet mesecev (od septembra 2011 do konca maja 2012) vsem mamam ob odpustu z oddelka izročili vprašalnik EPDS in jih prosili, da nam izpolnjenega vrnejo v priloženi kuverti. Obenem pa smo jim posredovali tudi kontaktne naslove in številke, kamor se lahko obrnejo v primeru kakršnihkoli težav, ter jim ponudili možnost svetovanja pri nas, če bi ga potrebovali. Izpolnjene vprašalnike smo vrednotili skladno z navodili. $\mathrm{Da}$ bi pridobili čim več izpolnjenih vprašalnikov ter bi tako $\mathrm{s}$ tem dobili boljši vpogled $\mathrm{v}$ izraženost poporodnega depresivnega razpoloženja pri mamah bolnih oziroma hospitaliziranih novorojenčkov, je bilo reševanje vprašalnikov povsem anonimno (mame so tako lahko le poslale izpolnjen vprašalnik, iz katerega ni bila razvidna identiteta $-\mathrm{v}$ tem delu raziskave tako nismo zbirali nobenih drugih podatkov).

V drugem delu raziskave smo s pomočjo NBAS ocenili vedenje novorojenčkov v prisotnosti mame ali obeh staršev, ki so privolili v sodelovanje. NBAS je izvedla certificirana in izkušena ocenjevalka, diplomirana medicinska sestra. Mame so pred izvedbo NBAS izpolnile vprašalnik za ocenjevanje otrokovih značilnosti in doživljanja staršev. Enak vprašalnik z dodatnimi vprašanji za oceno preizkusa NBAS so izpolnile tudi po opravljenem preizkusu. Ob odpustu z oddelka smo tudi tej skupini mam izročili vprašalnik EPDS.

Priložnostna narava vzorca in zasnova raziskave ne omogočata zahtevnejše statistične analize podatkov. Zaradi tega smo se pri obdelavi in prikazovanju podatkov omejili na nekatere osnovne mere opisne statistike. Izračunali smo mediane grupiranih podatkov, minimalne ter maksimalne vrednosti rezultatov, odstotke in frekvence. Poleg osnovnega grafičnega prikazovanja (npr. frekvenčne porazdelitve podatkov) smo nekod vzorec opisali tudi numerično. Pri primerjavi naših deležev $\mathrm{s}$ populacijskim deležem smo uporabili Clopper-Pearsonov postopek za izračun intervala zaupanja. Za primerjavo razlik med medianama dveh odvisnih vzorcev smo uporabili Wilcoxonov test. Za primerjavo dveh deležev v dveh različnih vzorcih smo izračunali $\chi^{2}$ test.

\section{Rezultati}

\section{Izraženost poporodnega depresivnega razpoloženja pri mamah novorojenčkov, ki so bili hospitalizirani na Kliničnem oddelku za neonatologijo Pediatrične klinike v Ljubljani}

Porazdelitev rezultatov na vprašalniku EPDS je prikazana na sliki 1 . Rezultati so se nahajali $\mathrm{v}$ razponu med 0 in 25 točk. Aritmetična sredina rezultatov je bila 8,52, standardna deviacija 5,09 ter mediana 8 .

Za ugotavljanje poporodnega depresivnega razpoloženja smo uporabili razmejitveno vrednost 10 točk, ki velja za slovenski prostor (Koprivnik in Plemenitaš, 2005). Delež mam, ki so dosegle ali presegle razmejitveno vrednost, je bil 38,1 \% (95 \% interval zaupanja = 26,151,2). V primerjavi z odstotkom mam z izraženimi simptomi poporodne depresije $\mathrm{v}$ slovenski populaciji $(21,3$ \%) je v opravljeni raziskavi ta delež statistično pomembno višji. 


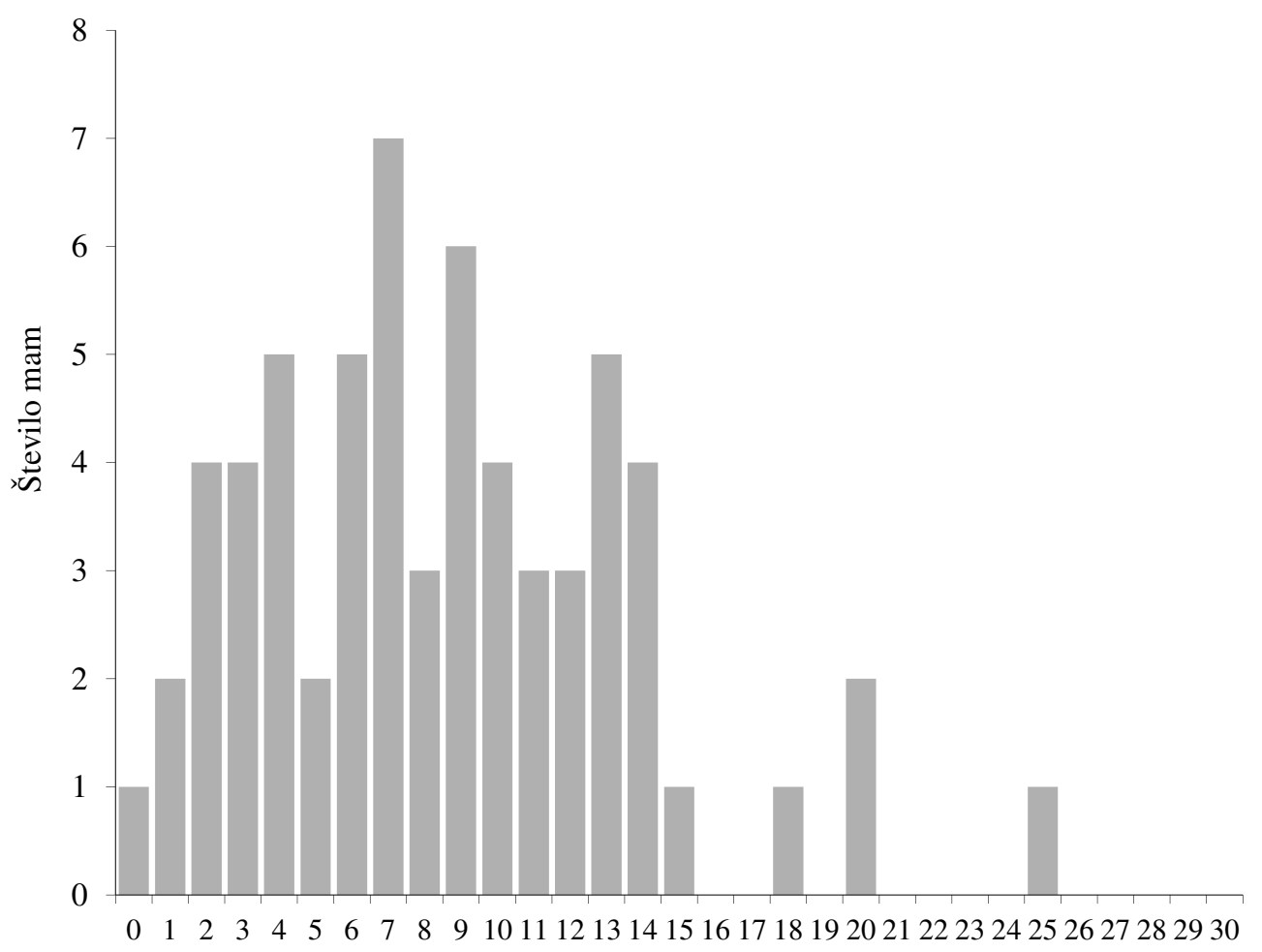

Skupni dosežek na EPDS

Slika 1. Frekvenčna porazdelitev skupnih dosežkov vseh udeleženk na vprašalniku EPDS.

Med vsemi udeleženkami jih je 22,2 \% (95\% interval zaupanja $=12,6-34,6)$ doseglo rezultat 13 ali več, kar je razmejitvena vrednost za odkrivanje težjih oblik poporodne depresije. Tudi ta odstotek je $\mathrm{v}$ primerjavi $\mathrm{z}$ odstotkom mam, ki so dosegle 13 točk ali več v slovenski populaciji $(10,1 \%)$, statistično pomembno višji.

Iz slike 2 lahko vidimo, da so mame najpogosteje navajale, da so se večino časa po nepotrebnem obremenjevale, kadar so šle stvari narobe (odgovori za 1,2 , in 3 točke na tretje vprašanje). Najmanj pogosto so mame poročale o samomorilnih mislih (10. vprašanje), kjer jih je 60 poročalo, da nikoli niso pomislile, da bi si kaj naredile.

\section{Primerjava odgovorov na vprašalniku o otrokovih značilnostih in doživljanju mam pred in po izvedbi NBAS}

S pomočjo vprašalnika za ocenjevanje otrokovih značilnosti in doživljanja mam smo pridobili nekatere dodatne informacije o otrokovih temperamentnih značilnostih ter informacije o doživljanju mam. Zanimalo nas je, ali mame temperamentne značilnosti svojih otrok doživljajo različno pred in po izvedbi NBAS.

Pri izračunu srednje vrednosti odgovorov pri vprašanjih, ki se nanašajo na značilnosti otroka in doživljanje mam, smo uporabili mediano za grupirane podatke. Glede na majhen razpon možnih odgovorov (od 1 do 5) smo se na ta način izognili, da bi podatki, ki ekstremno odstopajo od ostalih podatkov, bistveno vplivali na srednjo vrednost.
Iz tabele 1 je razvidno, da je pri drugem vprašanju srednja vrednost odgovorov, ki so jih podale mame, enaka pred in po izvedbi NBAS. V treh primerih (vprašanje 1, 6 in 7) je srednja vrednost odgovorov, ki so jih mame podale pred NBAS, višja kot po izvedbi NBAS. Pri ostalih petih vprašanjih pa je srednja vrednost odgovorov, ki so jih mame podale po izvedbi NBAS, višja kot pred njim. Iz Tabele 1 lahko tudi vidimo, da pri nobenem vprašanju, razen pri 7. vprašanju o težavnosti hranjenja, razlike med srednjimi vrednostmi pred in po izvedenem NBAS niso statistično pomembne.

Odgovore na odprto vprašanje: »Glede česa ste trenutno najbolj zaskrbljeni?" s smo glede na vsebino razvrstili v štiri kategorije:

1. glede osebnega počutja,

2. glede skrbi za novorojenčka (rokovanje $\mathrm{z}$ njim, hranjenje, prilagoditev na novo okolje ...),

3. glede otrokovega zdravstvenega stanja (diagnoze, preiskav, posledic bolezni in razvoja ...),

4. nisem zaskrbljena glede ničesar.

Pred in po NBAS je bilo največ mam zaskrbljenih glede otrokovega zdravstvenega stanja $\left(N_{\text {pred }}=17 ; N_{p o}=\right.$ 14), sledili so jim odgovori glede skrbi za novorojenčka $\left(N_{\text {pred }}=8 ; N_{p o}=7\right)$. Najmanjkrat so mame odgovorile, da so zaskrbljene glede svojega osebnega počutja $\left(N_{\text {pred }}=1\right.$; $\left.N_{p o}=1\right)$ ter da niso zaskrbljene glede ničesar $\left(N_{\text {pred }}=1 ; N_{p o}\right.$ $=1)$. Mame so lahko podale več odgovorov. 


\section{Ocene koristnosti izvedbe NBAS}

Obenem smo želeli tudi pridobiti informacije o tem, kako koristnost izvedbe NBAS, ki se pogosto uporablja kot pripomoček za povečevanje starševskih kompetenc oziroma kot pripomoček za spodbujanje interakcije med starši in otroki, ocenjujejo mame, vključene v našo raziskavo. Pri izračunu srednje vrednosti smo uporabili mediano za grupirane podatke.
Iz tabele 2 je razvidno, da je srednja vrednost odgovorov pri vseh vprašanjih višja od 4. Vidimo lahko, da je pri vseh vprašanjih najvišji odstotek odgovorov 5, kar pomeni, da so mame najbolj pogosto NBAS opisovale kot pripomoček, koristen za spoznavanje svojega otroka. Njegovo uporabo so ocenile kot koristno za otroka. NBAS bi si zelo želele še kdaj ponoviti ter bi ga zelo priporočile tudi drugim staršem.

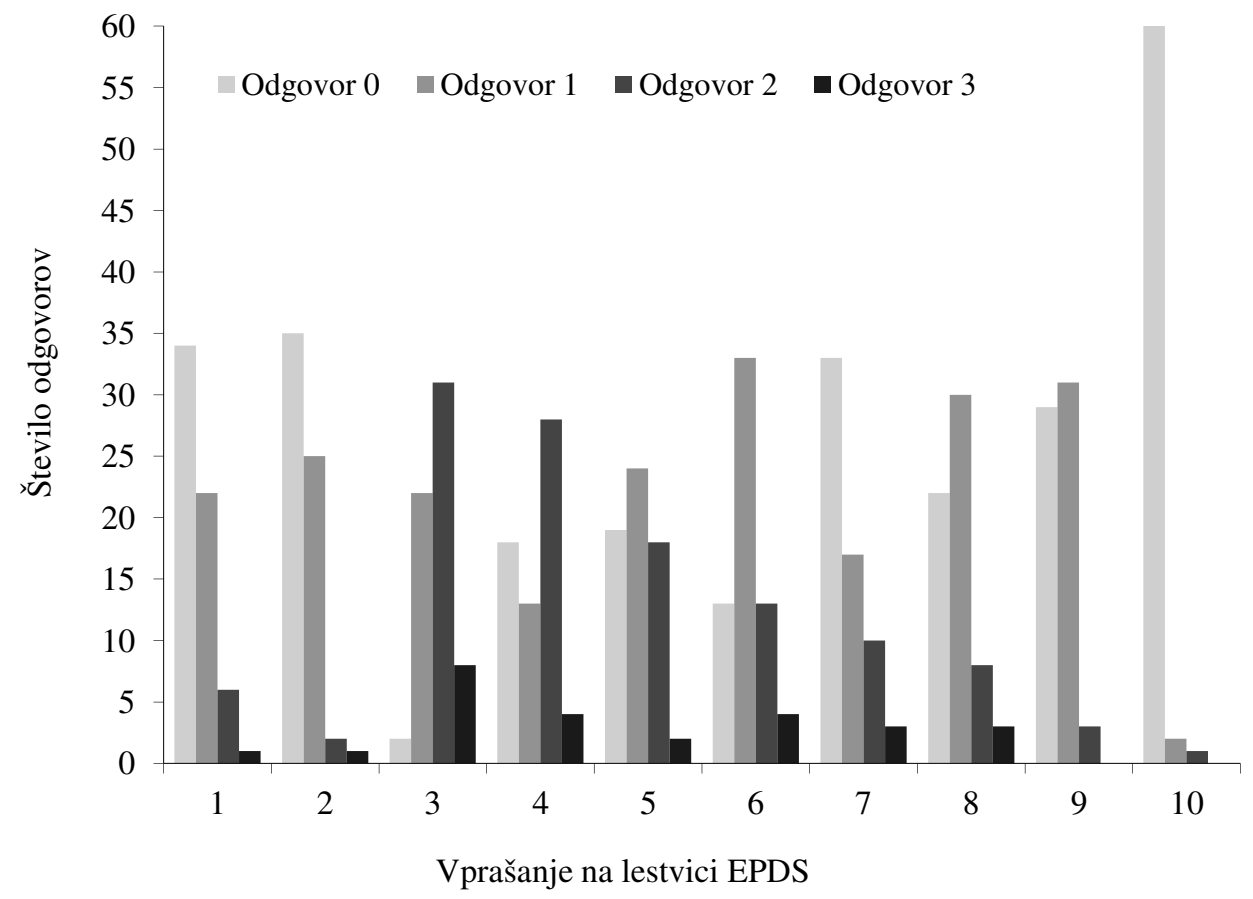

Slika 2. Frekvenčna porazdelitev posameznih odgovorov $(0,1,2,3)$ mam na vprašanja lestvice EPDS.

Tabela 1. Mediane grupiranih podatkov ter razpon odgovorov pri vprašanjih, ki se nanašajo na značilnosti otroka in na doživljanje mam, in smo jih zastavili mamam pred $(N=26)$ ter po $(N=24)$ izvedenem $N B A S$

\begin{tabular}{|c|c|c|c|c|c|c|c|c|}
\hline \multirow{2}{*}{ Vprašanje } & \multicolumn{3}{|c|}{ pred NBAS } & \multicolumn{3}{|c|}{ po NBAS } & \multicolumn{2}{|c|}{ Wilcoxonov test } \\
\hline & $M d n$ & Min & $\operatorname{Max}$ & $M d n$ & Min & $\operatorname{Max}$ & $Z$ & $p$ \\
\hline $\begin{array}{l}\text { 1. Moj otrok je zelo razdražljiv (1) / zelo } \\
\text { miren (5). }\end{array}$ & 3,94 & 2 & 5 & 3,89 & 3 & 5 & $-0,28$ & 0,78 \\
\hline $\begin{array}{l}\text { 2. Moj otrok spi zelo slabo (1) / zelo } \\
\text { dobro (5). }\end{array}$ & 4,40 & 3 & 5 & 4,40 & 3 & 5 & $-0,83$ & 0,41 \\
\hline $\begin{array}{l}\text { 3. Moj otrok je zelo zaspan (1) / zelo } \\
\text { buden (5). }\end{array}$ & 2,75 & 1 & 5 & 3,05 & 2 & 4 & $-1,12$ & 0,27 \\
\hline $\begin{array}{l}\text { 4. Moj otrok sploh ne (1) /vedno (5) } \\
\text { opazuje in spremlja okolje. }\end{array}$ & 3,81 & 2 & 5 & 3,93 & 2 & 5 & $-1,00$ & 0,32 \\
\hline $\begin{array}{l}\text { 5. Moj otrok me sploh ne pogleda }(1) / \\
\text { me vedno pogleda }(5) \text {. }\end{array}$ & 4,28 & 2 & 5 & 4,40 & 2 & 5 & $-1,13$ & 0,26 \\
\hline $\begin{array}{l}\text { 6. Svojega otroka težko pomirim (1) / z } \\
\text { lahkoto pomirim (5). }\end{array}$ & 3,89 & 3 & 5 & 3,84 & 3 & 5 & $-0,30$ & 0,76 \\
\hline $\begin{array}{l}\text { 7. Pri mojem otroku je hranjenje zelo } \\
\text { težavno (1) / zelo lahko (5). }\end{array}$ & 3,41 & 1 & 5 & 3,93 & 1 & 5 & $-2,15$ & 0,03 \\
\hline $\begin{array}{l}\text { 8. Glede nege in rokovanja } \mathrm{z} \text { otrokom } \\
\text { se počutim zelo negotovo (1) / zelo } \\
\text { samozavestno (5). }\end{array}$ & 3,65 & 2 & 5 & 4,05 & 2 & 5 & $-1,57$ & 0,12 \\
\hline $\begin{array}{l}\text { 9. Skrb za otroka se mi zdi zelo stresna } \\
\text { (1) / zelo nestresna (5). }\end{array}$ & 3,60 & 1 & 5 & 3,70 & 1 & 5 & $-1,31$ & 0,19 \\
\hline
\end{tabular}


Tabela 2. Mediane grupiranih podatkov ter odstotki odgovorov mam $(N=24)$ za posamezna vprašanja, ki se nanašajo na ocene koristnosti izvedbe NBAS

\begin{tabular}{|c|c|c|c|c|c|c|}
\hline Vprašanje & $M d n$ & $1(\%)$ & $2(\%)$ & $3(\%)$ & $4(\%)$ & $5(\%)$ \\
\hline NBAS se mi je zdel zelo nekoristen (1) / zelo koristen (5). & 4,5 & 0 & 0 & 13 & 29 & 58 \\
\hline $\begin{array}{l}\text { Ob izvedbi NBAS otroka nisem bolje spoznala (1) / sem } \\
\text { otroka bolje spoznala (5). }\end{array}$ & 4,3 & 0 & 0 & 21 & 37 & 42 \\
\hline NBAS mojemu otroku ni nič koristil (1) / je zelo koristil (5). & 4,3 & 0 & 4 & 17 & 33 & 46 \\
\hline $\begin{array}{l}\text { NBAS si ne bi želela več ponoviti (1) / bi si zelo želela še } \\
\text { kdaj ponoviti (5). }\end{array}$ & 4,2 & 0 & 9 & 30 & 9 & 52 \\
\hline $\begin{array}{l}\text { NBAS ne bi priporočila drugim staršem (1) / bi zelo } \\
\text { priporočila drugim staršem (5). }\end{array}$ & 4,7 & 0 & 0 & 12 & 13 & 75 \\
\hline
\end{tabular}

\section{Izraženost poporodnega depresivnega razpoloženja pri mamah bolnih novorojenčkov, pri katerih smo izvedli NBAS}

$\mathrm{V}$ raziskavi nas je zanimalo tudi, ali se skupina mam, pri katerih smo izvedli NBAS, razlikuje v izraženosti poporodnega depresivnega razpoloženja od skupine mam, pri katerih NBAS nismo izvedli.

V skupini mam, pri katerih smo izvedli tudi NBAS, je odstotek mam, ki so dosegle razmejitveno točko poporodne depresije, znašal 41,7 \%. V skupini mam, kjer NBAS nismo izvedli, pa je bil odstotek mam, ki so dosegle razmejitveno točko, 37,3 \%. Izračunani $\chi^{2}=0,036$ $(p=0,78)$ ne kaže statistično pomembnih razlik med obema skupinama.

V skupini mam, ki so sodelovale pri NBAS, je bilo 33,3 $\%$ tistih, ki so imele 13 točk ali več, kar je razmejitvena vrednost za odkrivanje težjih oblik poporodne depresije. V skupini mam, ki pri NBAS niso sodelovale, je bilo 21,6 \% tistih, ki so izpolnjevale kriterij za težjo obliko poporodne depresije. Tudi v tem primeru $\left(\chi^{2}=0,130 ; p=0,30\right)$ razlike med skupinama niso bile statistično pomembne.

\section{Razprava}

$\mathrm{V}$ raziskavi smo preučevali izraženost depresivnega razpoloženja pri mamah, katerih novorojenček je bil sprejet na Klinični oddelek za neonatologijo Pediatrične klinike v Ljubljani. Rezultati pričujoče raziskave kažejo med mamami novorojenčkov, ki se zdravijo na EINN, pomembno višji odstotek tistih, ki dosegajo razmejitveno točko poporodne depresije, kot je ugotovljena pojavnost poporodne depresije v slovenskem prostoru (Koprivnik in Plemenitaš, 2005). Prav tako je v naši raziskavi pomembno višji delež tistih mam, ki dosegajo razmejitveno vrednost za odkrivanje težjih oblik poporodne depresije, v primerjavi s pojavnostjo težjih oblik poporodne depresije v slovenski populaciji (Koprivnik in Plemenitaš, 2005). Zgodnja hospitalizacija novorojenčka predstavlja pomemben dejavnik, ki lahko vpliva na izraženost poporodnega depresivnega razpoloženja pri mamah. Slednje navajajo tudi drugi avtorji (Erdem, 2010; Yurdakul idr., 2009), ki ugotavljajo, da imajo mame, katerih otrok se zdravi na EINN, višje izraženo stopnjo depresivnosti in anksioznosti v primerjavi z mamami zdravih novorojenčkov. Zgodnja hospitalizacija zaradi otrokovih zdravstvenih težav ter stres kot posledica zahtevnejše nege in skrbi za otroka predstavljata pomembna dejavnika tveganja za nastanek poporodne depresije (Beck, 2002; Drglin, 2009; Globevnik Velikonja, 2009b).

Brazelton (1999) navaja, da mame, ki imajo svojega novorojenčka na EINN, pogosto prevzemata občutka krivde in odgovornosti. Očitajo si, da so one tiste, ki so spravile otroka $v$ nevarnost ter bi morale ravnati drugače, da do tega ne bi prišlo. Rezultati opravljene raziskave kažejo, da so mame pogosto navajale, da so se po nepotrebnem obremenjevale, kadar so šle stvari narobe. Najmanj pogosto so mame poročale o samomorilnih mislih, kar se sklada z ugotovitvami drugih avtorjev (pregled raziskav v Pope, Watts, Evans, McDonald in Henderson, 2000), ki navajajo, da je tveganje za samomor v tej specifični populaciji kar šestkrat manjše kot sicer pri depresivnih ženskah. Materinstvo namreč predstavlja močan zaščitni dejavnik.

$\mathrm{V}$ opravljeni raziskavi smo preverjali možnosti in koristnosti uvajanja uporabe NBAS kot pripomočka za spodbujanje interakcije med starši in otroki ter kot pripomočka za povečevanje starševskih kompetenc.

Pri ocenjevanju otrokovih značilnosti so mame po izvedenem NBAS pogosteje opisovale, da je njihov otrok bolj buden, pogosteje spremlja okolje, večkrat vzpostavi očesni stik z njimi kot so opisovale pred izvedenim NBAS. Po izvedenem NBAS so se mame glede nege in rokovanja z otrokom počutile bolj samozavestne ter se jim je skrb za otroka zdela manj stresna. Hranjenje otroka so po NBAS ocenjevale kot manj težavno kot pred njegovo izvedbo. Razlike med ocenami otrokovih lastnosti in lastnih kompetenc (razen pri vprašanju o težavnosti hranjenja) sicer niso statistično pomembne, vendar pa razlike med ocenami pred in po izvedbi NBAS kažejo v smer izražanja večjega poznavanja otrokovih odzivov in višjega občutka lastne kompetentnosti. K nepomembnosti razlik med ocenami pred in po izvedbi NBAS verjetno prispevajo tako majhen vzorec $\mathrm{v}$ raziskavo vključenih mam, kot tudi kratek interval med prvim in drugim ocenjevanjem. Raziskave (npr. Hawthorne, 2009) sicer kažejo, da ima uporaba NBAS pri mamah otrok, ki so bili zdravljeni na EINN, pozitiven učinek na njihovo zaznavo otroka. Mame tekom NBAS lahko bolj podrobno spoznajo, s kakšnim 
vedenjskim razponom se odziva njihov novorojenček na dražljaje iz okolja, kakšne so njegove sposobnosti prilagajanja ter posledično drugače ocenijo nekatere otrokove sposobnosti. Ena od največjih prednosti pri uporabi lestvice NBAS je namreč prav ta, da starše lahko opozorimo in naredimo bolj občutljive za sposobnosti in odgovore, ki jih že zmore njihov novorojenček (Brazelton, 1999). K nepomembnosti razlik je verjetno prispevalo tudi to, da se je NBAS v pričujoči raziskavi običajno izvajal takrat, ko se je bližal odhod novorojenčka domov. Pred tem so bile mame že vključene v nego svojega otroka, kar je lahko vplivalo na njihovo zmanjšano negotovost, prav tako pa se je zvišal tudi njihov občutek kompetentnosti v starševski vlogi (Gale idr., 2004; Globevnik Velikonja, 2009b).

$\mathrm{V}$ pričujoči raziskavi so mame pred ter po izvedenem NBAS odgovorile na vprašanje: »Glede česa ste trenutno najbolj zaskrbljeni?«. V obeh primerih jih je največ odgovorilo, da jih najbolj skrbi otrokovo zdravstveno stanje, ki se nanaša na skrbi glede diagnoze, preiskav, posledic bolezni ter nadaljnjega razvoja. Slednje je običajno tudi najbolj pogosta skrb vseh staršev, katerih otrok se zdravi na EINN (Johnson, 2011).

Naslednje so mame tako pred kot po izvedenem NBAS izpostavile skrb za novorojenčka, ki se nanaša na rokovanje $\mathrm{z}$ njim, hranjenje, prilagoditev na novo okolje in podobno. Že mame zdravih novorojenčkov se običajno sprašujejo, ali bodo znale dovolj dobro skrbeti za svojega novorojenčka ter ali bodo dovolj dobre mame (Pope idr., 2000). Ko je novorojenček zaradi nedonošenosti in/ali zaradi bolezni sprejet na EINN, se prej omenjena vprašanja še stopnjujejo, saj po odhodu domov otrok običajno potrebuje posebno obravnavo in nego, kar prinaša mami oziroma staršem dodatno odgovornost, skrbi ter stres (Beck, 2002).

$\mathrm{V}$ opravljeni raziskavi je večina mam NBAS ocenila kot zelo koristen pripomoček, ob katerem so bolje spoznale svojega otroka. Večina jih je opisala, da je NBAS koristil tudi njihovemu otroku ter bi si ga želele še kdaj ponoviti, obenem pa bi ga zelo priporočile tudi drugim staršem. Tudi v nekaterih drugih raziskavah (npr. Hawthorne, 2009; Hawthorne, 2010) starši ocenjujejo NBAS kot koristen pripomoček, ki jim je pomagal pri spoznavanju in razumevanju novorojenčkovih potreb ter pri pridobivanju samozaupanja v vlogi staršev. Starši pridobijo zaupanje vase in v svoje sposobnosti, da bodo znali razumeti in skrbeti za svojega otroka. Lažje tudi prepoznavajo otrokove potrebe in posledično učinkoviteje ukrepajo (Hawthorne in Hutchon, 2008).

$\mathrm{V}$ pričujoči raziskavi nas je zanimalo, ali se skupina mam, pri katerih smo izvedli NBAS, razlikuje $\mathrm{v}$ izraženosti poporodnega depresivnega razpoloženja $\mathrm{v}$ primerjavi s skupino mam, kjer NBAS nismo izvedli. Pri mamah, ki so sodelovale pri NBAS, je bil sicer nekoliko višji delež tistih mam, ki so dosegle razmejitveno točko poporodne depresije, $\mathrm{v}$ primerjavi $\mathrm{z}$ mamami, ki pri NBAS niso sodelovale, vendar razlika med obema skupinama ni bila statistično pomembna. Prav tako je bilo v skupini mam, ki so sodelovale pri NBAS, več tistih, ki so dosegale kriterij za odkrivanje težjih oblik poporodne depresije, $\mathrm{v}$ primerjavi $\mathrm{z}$ mamami, ki pri NBAS niso sodelovale, vendar tudi ta razlika med obema skupinama ni bila statistično pomembna. NBAS se na oddelku ne opravlja rutinsko pri vseh otrocih, temveč po presoji strokovnega tima običajno pri otrocih in starših, kjer osebje opazi težave pri vključevanju staršev v nego in skrb za otroka. Slednje pa nekateri avtorji (npr. Cox in Holden, 2003; Holden idr., 1989; Murray in Cooper, 1996; Murray idr., 2010) povezujejo s poporodno depresijo. Kot intervencijski pripomoček za vzpostavljanje odnosa med otrokom in starši je NBAS koristen pri spoznavanju in razumevanju novorojenčkovih potreb ter pri pridobivanju samozaupanja v vlogi staršev (npr. Hawthorne, 2009; Hawthorne, 2010). Ob tem pa je izraženost poporodnega depresivnega razpoloženja posledično lahko manjša (npr. Cox in Holden, 2003). K nepomembnosti razlik med obema skupinama $v$ naši raziskavi je verjetno prispevala majhnost vzorca kot tudi to, da so vse mame dobile vprašalnik EPDS ob odpustu.

Pričujoča raziskava predstavlja v slovenskem prostoru prvi poskus ugotavljanja depresivne simptomatike pri mamah novorojenčkov, zdravljenih na EINN in uporabe NBAS kot intervencijskega pripomočka za spodbujanje zgodnje interakcije med novorojenčkom in starši. Pri interpretaciji ugotovitev moramo biti previdni, saj zaradi nekaterih pomanjkljivosti raziskave (majhnost vzorca in priložnostna narava raziskave) nismo mogli izvesti zahtevnejših statističnih analiz in zaključevati $\mathrm{z}$ večjo gotovostjo.

Pomanjkljivost opravljene raziskave je tudi pomanjkanje podatkov o nekaterih drugih dejavnikih, ki bi tudi lahko vplivali na izraženost maminega poporodnega depresivnega razpoloženja, na primer težavnost otrokovega zdravstvenega stanja, trajanje hospitalizacije, pretekle depresivne epizode in podobno. Obenem nismo imeli točnega vpogleda $v$ to, koliko časa po porodu so mame izpolnjevale vprašalnik EPDS (saj so bili nekateri med njimi vrnjeni anonimni), prav tako pa nismo imeli podatkov o mamah, ki po zaključeni hospitalizaciji vprašalnika niso vrnile.

Kljub omenjenim pomanjkljivostim ugotovitve opravljene raziskave kažejo, da predstavlja zgodnja hospitalizacija novorojenčka pomemben dejavnik, ki lahko vpliva na izraženost poporodnega depresivnega razpoloženja pri mamah. Rutinska uporaba EPDS na EINN ter ozaveščanje žensk o poporodni depresiji bi lahko pripomogla $\mathrm{k}$ boljši prepoznavi poporodne depresije. Slednje je zelo pomembno, saj lahko z zdravljenjem močno vplivamo na potek depresije.

$\mathrm{V}$ opravljeni raziskavi smo preverjali možnost in koristnost uvajanja uporabe NBAS kot pripomočka za spodbujanje interakcije med starši in otroki ter kot pripomočka za povečevanje starševskih kompetenc in približevanja potrebam staršev. Mame so NBAS večinoma ocenile kot zelo koristen pripomoček pri spoznavanju otroka, ki bi ga priporočile tudi vsem drugim staršem. 
S tega vidika je smiselno NBAS v večji meri vključevati $\mathrm{V}$ redno klinično delo na oddelku za zdravljenje novorojenčkov. Čeprav se NBAS praviloma izvaja v prisotnosti obeh staršev, včasih celo vseh družinskih članov, zaradi objektivnih okoliščin (npr. prostorska stiska na oddelku, zaradi česar očetje pogosto niso prisotni $\mathrm{z}$ mamo ob otroku, druge obveznosti očetov, kot npr. skrb za starejše sorojence, delo ...) to ni bilo vedno mogoče. S sistematičnim izvajanjem NBAS v prisotnosti obeh staršev bi lahko ugotavljali tudi njegov učinek na doživljanje očetov. $\mathrm{Na}$ osnovi zbranih podatkov in podatkov iz literature pa bi bilo smiselno proučevati tudi odnos med maminim poporodnim depresivnim razpoloženjem in otrokovim vedenjem v obdobju novorojenčka.

\section{Literatura}

Alberts, A. E. (2005). Assessment, neonatal behavioral assessment scale. V C. B. Fisher in R. M. Lerner (ur.), Applied developmental science: An encyclopedia of research, policies, and programs (str. 111-115). Thousand Oaks, CA, ZDA: Sage.

American Psychiatric Association. (1994). Diagnostic and statistical manual of mental disorders $I V\left(4^{\text {th }}\right.$ ed.). Washington, DC, ZDA: American Psychiatric Association.

Beck, C. T. (2002). Revision of the Postpartum Depression Predictors Inventory. Journal of Obstetric, Gynecologic, \& Neonatal Nursing, 31(4), 394-402.

Brazelton, T. B. (1999). Otrok: Čustveni in vedenjski razvoj vašega otroka [Your Child's Emotional and Behavioral Development]. Ljubljana, Slovenija: Mladinska knjiga.

Brazelton, T. B. in Nugent, K. J. (2001). Neonatal Behavioral Assessment Scale (3rd ed.). London, Velika Britanija: Cambridge University Press.

Carr, A. (2006). The handbook of child and adolescent clinical psychology: A contextual approach. London, Velika Britanija: Routledge.

Cox, J. in Holden, J (2003). Perinatal mental health: A guide to the Edinburgh Postnatal Depression Scale (EPDS). Glasgow, Velika Britanija: Gaskell.

Diego, M. A., Field, T. in Hernandez-Reif, M. (2005). Prepartum, postpartum and chronic depression effects on neonatal behavior. Infant Behavior \& Development, 28(2),155-164.

Drglin, Z. (2009). Zima v srcu [Winter in the heart]. Ljubljana, Slovenija: Inštitut za varovanje zdravja.

Erdem, Y. (2010). Anxiety levels of mothers whose infants have been cared for in unit level-I of a neonatal intensive care unit in Turkey. Journal of Clinical Nursing, 19, 1738-1747.

Flacking, R., Ewald, U., Hedberg Nyqvist, K. in Starrin, B. (2006). Trustful bonds: A key to »becoming a mother« and to reciprocal breastfeeding: Stories of mothers of very preterm infants at a neonatal unit. Social Science \& Medicine, 62, 70-80.
Gale, G., Franck, L. S., Kools, S. in Lynch, M. (2004). Parents' perceptions of their infant's pain experience in the NICU. International Journal of Nursing Studies, 41, 51-58.

Globevnik Velikonja, V. (2009a). Psihoterapevtska obravnava poporodne depresije [Psychotherapeutic treatmnet of postpartum depression]. V B. Bratanič (ur.), Dojenje - smo pripravljeni na nove izzive? (str. 39-45). Ljubljana, Slovenija: Nacionalni odbor za spodbujanje dojenja, Društvo UNICEF Slovenija.

Globevnik Velikonja, V. (2009b). Vloga psihologa pri stiskah žensk ob fetalni smrti, smrti novorojenčka, hudih okvarah in boleznih [The role of psychologist in women after fetal death, neonatal death, serious disorders and diseases]. V U. Križaj Hacin (ur.), Duševno zdravje in nosečnost, porod ter zgodnje starševstvo (str. 40-48). Ljubljana, Slovenija: Inštitut za varovanje zdravja Republike Slovenije.

Hawthorne, J. (2005). Using the Neonatal Behavioural Assessment Scale to support parent-infant relationships. Infant, 1(6), 213-218.

Hawthorne, J. (2009). Promoting development of the early parent-infant relationship using the Neonatal Behavioural Assessment Scale. V J. Barlow in P. O. Svanberg (ur.), Keeping the baby in mind: Infant mental health in practice (str. 39-51). London, Velika Britanija: Routledge.

Hawthorne, J. (2010). Supporting parents in the NICU/ SCBU using the NBAS (or Neonatal Behavioural Assessment Scale) to understand the behaviour of the infant. V D. Paro Panjan (ur.), Novorojenček in družina: Pomen razumevanja novorojenčkovega vedenja (str. 18). Ljubljana, Slovenija: Klinični oddelek za neonatologijo, Pediatrična klinika, Univerzitetni Klinični Center.

Hawthorne, J. in Hutchon, B. (2008). The Brazelton Neonatal Behavioural Assessment Scale and parentinfant relationships. V D. Paro Panjan (ur.), Vedenjski vzorci novorojenčka v luči zgodnjega razvoja (str. 2933). Ljubljana, Slovenija: Služba za neonatologijo.

Holden, J. M., Sagovsky, R. in Cox, J. L. (1989). Counselling in a general practice setting: Controlled study of health visitor intervention in treatment of postnatal depression. British Medical Journal, 298, 223-226.

Johnson, M. R. (2011). A NICU parent support group using scrapbooking: The PAGes Project. Developmental Observer, 4(2), 10-10.

Jones, N. A., Field, T., Fox, N. A., Davalos, M., Lundy B. in Hart, S. (1998). Newborns of mothers with depressive symptoms are physiologically less developed. Infant Behavior \& Development, 21(3), 537-541.

Koprivnik, P. in Plemenitaš, A. (2005). Pojavnost depresij v poporodnem obdobju v slovenskem vzorcu [Incidence of depression in the postpartum period - Slovene sample]. Medicinski razgledi, 44, 139-145. 
Koprivnik, P. in Plemenitaš, A. (2009). Zakaj tudi V Sloveniji ne izvajamo presejanja na poporodno depresijo? [Screening for Postpartum Depression Why is it not implemented in Slovenia?]. Zdravniški vestnik, 78, 261-264.

Lee, D., Yip, A., Leung, T. in Chung, T. (2000). Identifying women at risk of postnatal depression: Prospective longitudinal study. Hong Kong Medical Journal, 6(4), 349-354.

Lundy, B. L., Jones, N. A., Field, T., Nearing, G., Davalos, M., Pietro P. A., Schanberg, S. in Kuhn, C. (1999). Prenatal depression effects on neonates. Infant Behavior \& Development, 22(1), 119-129.

Murray, L. in Cooper, P. J. (1996). The impact of postpartum depression on child development. International Review of Psychiatry, 8(1), 55-63.

Murray, L., Stanley, C., Hooper, R. in King, F., FioriCowley, A. (1996). The role of infant factors in postnatal depression and mother-infant interactions. Developmental Medicine \& Child Neurology, 38(2), 109-119.

Murray, L., Arteche, A., Fearon, P., Halligan, S., Croudace, T. in Cooper, P.(2010). The effects of maternal postnatal depression and child sex on academic performance at age 16 years: A developmental approach. Journal of Child Psychology and Psychiatry, 51(10), 1150-1159.

Nugent, K. J. (1985). Using the NBAS With Infants and Their Families: Guidelines for Intervention. Boston, MA, ZDA: The Brazelton Institute, Division of Developmental Medicine, Children's Hospital Boston.

Pope, S., Henderson, J., Watts, J., McDonald, S., Evans S. in Kosky, M. (2000). Postnatal depression: Not just the baby blues. Canberra, Avstralija: National Health and Medical Research Council.

Pope, S., Watts, J., Evans, S., McDonald, S. in Henderson, J. (2000). Postnatal depression: A systematic review of published scientific literature to 1999. Canberra, Avstralija: National Health and Medical Research Council.

Skočir, A. P. (2005). Glavne značilnosti poporodne depresije [Main Features of Post-partum Depression]. Obzornik zdravstvene nege, 39, 119-129.

World Health Organization. (1992). International Classification of diseases - ICD 10. Geneva, Švica: WHO library cataloguing in publication data.

Yurdakul, Z., Akman, I., Kuşçu, M. K., Karabekiroglu, A., Yaylah, G., Demir, F. in Özek E. (2009). Maternal psychological problems associated with neonatal intensive care admission. International Journal of Pediatrics, 2009. 